\title{
Effects of distal pancreatectomy and splenectomy on outcomes in patients undergoing cytoreductive surgery and hyperthermic intraperitoneal chemotherapy with $\mathrm{CC} / 0$ resection
}

\author{
Sitoredüktif cerrahi ve CC/0 rezeksiyonla hipertermik intraperitoneal kemoterapi uygulanan \\ hastalarda distal pankreatektomi ve splenektominin sonuçlara etkisi
}

\author{
(D) Yiğit Mehmet ÖZGÜN ${ }^{1}$, (DVolkan ÖTER ${ }^{1}$, (DErol PişKIN ${ }^{1}$, (D Muhammet Kadri ÇOLAKOĞLU1 \\ (D) Osman AYDIN ${ }^{1}$, (D) Erdal Birol BOSTANCl² \\ Department of ${ }^{1}$ Gastroenterological Surgery, Ankara City Hospital, Ankara \\ Department of ${ }^{2}$ Gastroenterological Surgery, University of Health Science, Ankara City Hospital, Ankara
}

\begin{abstract}
Background and Aims: This study aims to determine the early and late postoperative effects of distal pancreatectomy plus splenectomy in patients who underwent cytoreductive surgery and hyperthermic intraperitoneal chemotherapy and achieved $\mathrm{CCO}$ resection due to peritoneal carcinomatosis. Materials and Method: All patients who underwent a cytoreductive surgery and hyperthermic intraperitoneal chemotherapy procedure due to peritoneal carcinomatosis of various tumors in our clinic between 2014 and 2020 were included in the study. Data from all patients who underwent additional distal pancreatectomy plus splenectomy were analyzed retrospectively. Results: The cytoreductive surgery and hyperthermic intraperitoneal chemotherapy procedure with $\mathrm{CC} / 0$ resection was performed on 85 of 136 patients diagnosed with peritoneal carcinomatosis. Of these patients, 13 (15.3\%) had undergone distal pancreatectomy plus splenectomy together with the main procedure. The mean hospital stay was 15 (range, 5-50) days in patients who underwent distal pancreatectomy plus splenectomy, whereas it was 13 (range, 4-109) days in those who did not, and the difference was statistically insignificant. The most common major complications seen in the distal pancreatectomy plus splenectomy group were an anastomotic leak, enterocutaneous fistula, and intraabdominal abscess. The 30-day mortality was two (15.38\%) and one (1.38\%) in the group with and the group without distal pancreatectomy plus splenectomy, respectively. When the groups were evaluated, the median survival time was 19 months in the cytoreductive surgery and hyperthermic intraperitoneal chemotherapy group and 18 months in the cytoreductive surgery and hyperthermic intraperitoneal chemotherapy + distal pancreatectomy plus splenectomy group. This difference was statistically insignificant $(p=0.382)$. Conclusion: The addition of distal pancreatectomy plus splenectomy increased major postoperative complications in patients undergoing cytoreductive surgery and hyperthermic intraperitoneal chemotherapy but did not affect overall survival. We think distal pancreatectomy plus splenectomy can be performed for a complete cytoreduction if necessary. However, it increases major postoperative complications, and patient follow-up should be done accordingly.
\end{abstract}

Key words: Hyperthermic intraperitoneal chemotherapy, cytoreductive surgery, distal pancreatectomy, splenectomy
Giriş ve Amaç: Bu çalışmanın amacı, peritoneal karsinomatozis nedeniyle sitoredüktif cerrahi ve hipertermik intraperitoneal kemoterapi uygulanan ve komplet sitoredüksiyon sağlanan hastalarda distal pankreatektomi+splenektominin erken ve geç postoperatif etkilerini belirlemektir. Gereç ve Yöntem: Kliniğimizde 2014-2020 yılları arasında çesitli tümörlerin peritoneal karsinomatozisi nedeniyle sitoredüktif cerrahi ve hipertermik intraperitoneal kemoterapi işlemi yapılan tüm hastalar çalışmaya dahil edildi. Ek distal pankreatektomi ve splenektomi yapılan tüm hastaların verileri retrospektif olarak analiz edildi. Bulgular: Peritoneal karsinomatozis tanısılla ameliyat edilen 136 hastanın 85'ine (komplet sitoredüksiyon rezeksiyonla) sitoredüktif cerrahi ve hipertermik intraperitoneal kemoterapi işlemi uygulandı. Bu hastaların 13'ünün (\%15.3) ana işleme ek olarak distal pankreatektomi + splenektomi uygulandı. Distal pankreatektomi ve splenektomi yapılan hastalarda ortalama yatıs süresi 15 (5-50) gün iken, yapılmayanlarda 13 (4-109) gündü ve aradaki fark istatistiksel olarak anlamsızdı. Distal pankreatektomi ve splenektomi yapılan grupta en sık görülen majör komplikasyon anastomoz kaçağı, enterokutanöz fistül ve intraabdominal apse idi. 30 günlük mortalite distal pankreatektomi ve splenektomi eklenen ve eklenmeyen gruplarda sırası ile 2 (\%15.38) ve 1 (\%1.38) idi. Gruplar değerlendirildiğinde; medyan sağkalım süresi sitoredüktif cerrahi ve hipertermik intraperitoneal kemoterapi grubunda 19 ay, sitoredüktif cerrahi ve hipertermik intraperitoneal kemoterapi + distal pankreatektomi ve splenektomili grupta 18 aydı ve istatistiksel olarak anlamlı değildi $(p=$ 0.382). Sonuç: Distal pankreatektomi ve splenektomi eklenmesi, sitoredüktif cerrahi ve hipertermik intraperitoneal kemoterapi uygulanan hastalarda postoperatif majör komplikasyonları arttırmaktadır, fakat genel ortalama sağkalımı etkilememiştir. Tam bir sitoredüksiyon için gerekirse distal pankreatektomi ve splenektomi yapılabileceğini düşünüyoruz ancak bu işlemin postoperatif majör komplikasyonların gelişimini arttırdığı bilinmeli ve buna göre hasta takibi yapılmalıdır.

Anahtar kelimeler: Hipertermik intraperitoneal kemoterapi, sitoredüktif cerrahi, distal pankreatektomi, splenektomi
Correspondence: Volkan ÖTER

Department of Gastrointestinal Surgery, Ankara City Hospital, Ankara, Turkey

E-mail: otervolkan@gmail.com
Özgün YM, Öter V, Piskin E, et al. Effects of distal pancreatectomy and splenectomy on outcomes in patients undergoing cytoreductive surgery and hyperthermic intraperitoneal chemotherapy with CC/O resection. The Turkish Journal of Academic Gastroenterology 2021;20:104-111. DOI: 10.17941/agd.978955

Manuscript received: 28.04.2021 • Accepted: 03.06.2021 


\section{INTRODUCTION}

Peritoneal carcinomatosis (PC) was previously considered as a terminal stage disease and was tried to be treated with palliative surgical procedures and systemic chemotherapy (1). Today, PC is accepted as a locoregional disease limited to the abdomen, and selected patients are effectively treated with cytoreductive surgery and hyperthermic intraperitoneal chemotherapy (CRS + HIPEC) treatment (2). Compared to systemic chemotherapy, very good results are obtained and long-term survival can be achieved especially in the treatment of colorectal malignancies, gastric cancers, pseudomyxoma peritonei, peritoneal metastases of ovarian carcinoma and malignant mesothelioma (3-5). In this complex and aggressive surgery, it is emphasized that the experience and learning curve of the center are very important in terms of postoperative outcomes (6). In addition, the completeness of cytoreduction (CC) score is better in experienced centers. The purpose of CC is to clear peritoneal metastases, to perform necessary organ resections and peritonectomies. Afterwards, HIPEC treatment can be performed with open or closed methods (7). After this procedure, $0.9 \%-5.8 \%$ mortality and $12 \%-52 \%$ morbidity rates can be observed (8). Studies have shown that postoperative serious complications (serious adverse events) increase early recurrences (9).

One of the dilemmas that arises when performing cytoreductive surgery and HIPEC procedure is pancreatic involvement of the tumor. While pancreaticoduodenectomy procedure, which may be necessary in pancreatic head and neck involvement, creates an obstacle for resection due to its additional high morbidity and mortality risk, resection appears as an option in front of the surgeon in distal pancreatic involvement. Distal pancreatectomy is a procedure that has postoperative complications and therefore may affect early and late results, but it does not prevent resectability as in peritoneal carcinomatosis with pancreatic head and neck involvement.

To our knowledge, there is insufficient data in the English literature regarding patients who underwent CRS + HIPEC with additional distal pancreatic and splenic resection (DPS), and the management to this issue is still unclear. The aim of this study is to determine the early and late postoperative effects of distal pancreatectomy plus splenectomy in patients who underwent CRS + HIPEC and achieved CCO resection due to peritoneal carcinomatosis.

\section{MATERIALS and METHOD}

This retrospective study is evaluated and approved by the ethics board of our center (Ankara City Hospital; Ethics board number: 24.03.2021, E2-21-353).
All patients who underwent CRS + HIPEC procedure due to peritoneal carcinomatosis of various tumors in our clinic between 2014 and 2020 were included in the study. Data of all patients who underwent additional distal pancreatectomy and splenectomy were found and analyzed retrospectively.

In the preoperative staging, the patients were evaluated according to their computed tomography $(\mathrm{CT})$, magnetic resonance imaging (MRI), upper and lower gastrointestinal endoscopy (if necessary), blood tests and performance status and prepared for the operation. All patients for whom CRS+HIPEC procedure was planned were discussed at the multidisciplinary tumor council before surgery and their treatment was decided. Patients who were not suitable for surgery or had palliative procedures were excluded from the study. HIPEC was performed to all patients after CRS. Degree of resection is reported as; CC/0: no macroscopic visible tumor, CC/1: $<2.5 \mathrm{~mm}$ residual tumoral implants, CC/2: residual tumoral implants between $2.5 \mathrm{~mm}$ and $2.5 \mathrm{~cm}$ and CC/3: implants over > $2.5 \mathrm{~cm}(7,10)$.

In CC/1, CC/2 and CC/3 resections, millimetric or macroscopic tumor is left behind, and therefore aggressive interventions such as distal pancreatectomy, splenectomy or diaphragm stripping may not be performed. Considering that the patients who underwent $\mathrm{CC} / 1, \mathrm{CC} / 2$ and $\mathrm{CC} / 3$ resections would affect the early and late results, only patients with CC/O complete resection were included in the study. The Eastern Cooperative Oncology Group (ECOG) score (11) was used in the preoperative evaluation of the patients, and patients with an ECOG value above 3 due to comorbid diseases were not operated and excluded from the study. Patients with extraabdominal metastases in the preoperative evaluation were also excluded from the study. The nutritional status of the patients was determined according to NRS 2002 (12), and patients in need were given adequate nutritional support preoperatively.

\section{Surgical Procedure (CRS + HIPEC)}

All operations were performed in the same center and by the same experienced surgical team. A midline incision between the xiphoid process and pubic tubercle was used in all operations. After a full abdominal exploration, peritoneal carcinomatosis index $(\mathrm{PCl})$ was determined as defined by Sugarbaker (13). According to the spread of the tumor, patients were performed cytoreductive surgery, five-zone peritonectomy and necessary multi-organ resections as described by Sugarbaker $(10,13)$. In all operations, total surgical time, amount of blood replace- 
ments, organ and peritoneal resections and urine output were recorded. When it was ensured that there was no visible tumor, the abdomen was washed with five liters of warm saline. For HIPEC, two inflow and two outflow drains were placed in the abdomen, and abdomen was temporarily closed for the closed system HIPEC treatment. All patients were administered HIPEC as Oxaliplatin $350 \mathrm{mg} /$ $\mathrm{m}^{2}$ in 5\% dextrose solution at 42-42.5 degrees for 30-60 minutes. In 15 patients, $15 \mathrm{mg} / \mathrm{m}^{2}$ Mitomycin-C was administered intraperitoneally, once for 60 minutes. After HIPEC treatment, the abdomen was washed again with five liters of warm saline and anastomoses, if any, were performed after this stage.

\section{Surgical Procedure (Distal pancreatectomy + splenectomy)}

In all patients, the distal pancreas was resected en bloc with the spleen. Since all patients were operated for non-pancreatic malignancies, radical anterograde modular pancreaticosplenectomy (RAMPS) was not performed in any case. Resection was performed until the surgical margin of the pancreas was thought to be tumor free (Figure 1). In suspicious cases, frozen section was studied to make sure of the negative margin. The pancreatic stump was closed manually with eight-shaped sutures using 3/0 silk suture, in all cases. Stapler and / or adhesive material such as fibrin glue was not performed in any of the cases. In cases without distal pancreatic involvement, only splenectomy was performed. These patients were not included in the study.

\section{Postoperative Stage and Data Analysis}

All patients were followed up in the intensive care unit after the operation. Patients were recorded in terms of gastrointestinal, hematological, urinary, respiratory and neurological complications and were followed up daily.

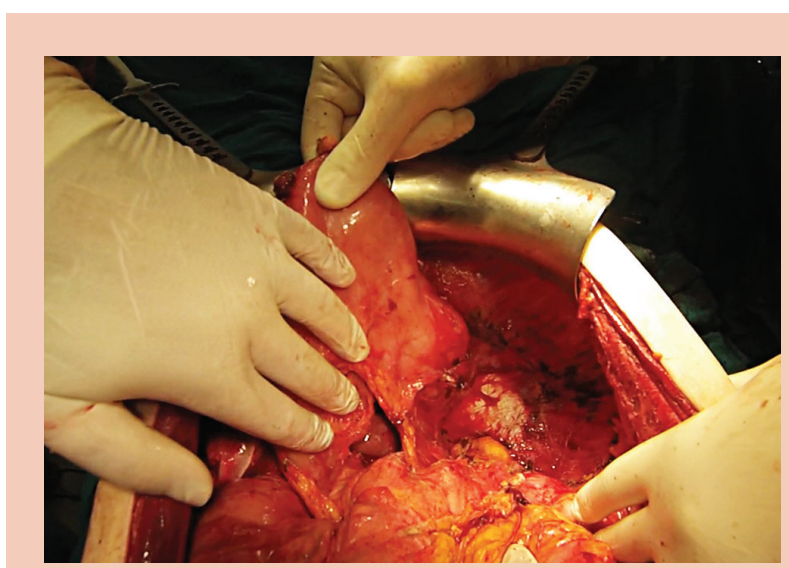

Figure 1. A case with total omentectomy, diaphragmatic stripping, and DPS.
Complications were reviewed retrospectively for the first 30 days. Complication grading was done according to the National Cancer Institute Common Terminology Criteria for Adverse Events (NCICTCAE) version 3.0 (14).

- Group 0: No complications

- Group 1: Patients with Grade 1, 2; minor complications

- Group 2: Patients with Grade 3, 4, 5; major complications

The patients were evaluated in three categories: no postoperative complications, minor complications, and major complications. Major complications were evaluated as grade 3 for endoscopic or CT/Ultrasound (USG) guided interventions, grade 4 for reoperation, and grade 5 for postoperative death. Complications were divided into three groups according to their grades. Patients with and without DPS were compared according to their demographic characteristics and development of complications.

\section{Statistical Analysis}

The data were evaluated with IBM SPSS Statistics program v. 21 for analysis. In evaluation process; frequency as number and percentages were used for categorical variables. Descriptive data were used as median, minimum, and maximum for numerical variables. Continuous variables were evaluated as mean value \pm standard deviation or median value (minimum-maximum) where applicable. Mann-Whitney U-test was applied for comparing median values, and the mean differences were evaluated by student's t-test. A p value $<0.05$ was considered statistically significant.

\section{RESULTS}

CRS + HIPEC procedure with $\mathrm{CC} / 0$ resection was performed on 85 patients out of 136 who were operated with the diagnosis of peritoneal carcinomatosis. It was evaluated that 13 of these patients (15.3\%) had undergone distal pancreatectomy + splenectomy together with the main procedure. While $46(54.1 \%)$ of the 85 patients who were operated were women, the mean age was $54.3 \pm 11.8$ years. There was no significant difference in terms of age and gender between patients who underwent DPS or not.

Considering the causes of peritoneal carcinomatosis, both groups were operated mostly for colorectal and gastric malignancies. Other causes were pseudomyxoma peritonei (PMP), ovarian cancer, intestinal adenocarcinoma, mesothelioma and neuroendocrine tumor (NET) of small intestine, in order of frequency. There was no 
statistical difference between the two groups in terms of primary tumor origin. While the mean $\mathrm{PCl}$ score of all operated patients was 7 (0-30), this number was 7 in patients who underwent DPS and 6 in patients who did not, and there was no statistically significant difference between the two groups ( $p=0.598)$. The patients with a $\mathrm{PCl}$ score of 0 were those who underwent prophylactic HIPEC or were operated for perforated appendix mucocele in an external center and who were performed complementary HIPEC by us. There were 12 (16.6\%) patients in CRS + HIPEC group and 2 (15.3\%) patients in DPS group who received prophylactic HIPEC. Median operation time was 7 (2-15) hours in all patients. This period was 7 (3-12) hours in patients with DPS, while it was 6.5 (2-15) hours in the group that did not, and there was no statistical difference. The need for peroperative blood transfusion occurred in 21 (25.3\%) patients while 2 of these 21 patients who received blood transfusion were in the CRS + HIPEC + DPS group, the remaining 19 patients were in CRS + HIPEC group but this difference was not statistically significant $(p=0.397)$. The preoperative mean albumin value of the patients was $4.2 \pm 0.4$ $\mathrm{gr} / \mathrm{L}$. The average number of resected organs was found to be $2(0-6)$, and the average number of peritonectomy areas described by Sugarbaker was found to be 2 (0-5). The numbers and $p$ values of both groups are presented in Table 1.

Postoperative complications were observed in 11 (84.61\%) patients in the DPS group, while in 37 (51.38) patients in the group without DPS, and the difference was statistically significant $(p=0.026)$. When we examined in terms of major and minor complications, major complications were seen in 7 (53.84\%) and 17 (23.61\%) patients, respectively, between the group that underwent DPS and the group that did not, and the difference was also statistically significant ( $p=0.02)$. Ostomy was performed in 21 (24.7\%) patients in total, and no difference was found between the groups in terms of ostomy ( $p$ : 0.397). The differences observed between the groups in terms of complications are presented in Table 1 and all complications observed are presented in Table 2.

The mean hospitalization period of all patients was 14 (4109) days. The mean was 15 (5-50) days in patients who underwent DPS, while it was 13 (4-109) days in those who did not, and the difference was statistically insignificant. When 85 patients were evaluated, 30-day mortality was observed in $3(3.5 \%)$ patients. One of them was in the CRS group and two were in the CRS + DPS group. As these two groups were compared in terms of 30-day mortality, no statistically significant difference was found $(p=0.06)$. One of these patients died due to anastomotic leak and septic shock, one due to pulmonary embolism and the other due to pancytopenia. Two of these patients were in the group which DPS was performed. One patient died 60 days after operation at the CRS + HIPEC group. When both groups were evaluated in terms of overall survival after excluding patients who died in 30 days the median survival time was 18 months (range; 1 - 80 months) in all patients, when groups were evaluated; the median survival time was 19 months (range; 1 - 80 months) in the CRS + HIPEC group and 18 months (range; 1 -47) in the group with CRS + HIPEC + DPS, and this difference was found to be statistically insignificant $(p=0.382)$.

\section{DISCUSSION}

Peritoneal carcinomatosis, which was previously considered to be inoperable, is now recognized as a locoregional disease with treatment, thanks to the innovations and developments in surgery and oncology in the last two decades (15). Cytoreductive surgery (SRC) and intraperitoneal chemotherapy treatment described by Spratt in cases of Pseudomyxoma peritonei in 1980 was developed by Sugarbaker and has taken the form applied today (16). Today, CRS + HIPEC treatment is used for curative purposes for gastric cancers, malignant mesothelioma and peritoneal metastases of some rare tumors, althou$\mathrm{gh}$ it is especially used for appendix mucinous tumors, colorectal and ovarian malignancies (16-17). The purpose of this treatment modality is to surgically resect all visible tumoral implants and to perform HIPEC in the same session for malignant cells that are not seen at the cellular level (18). Cytoreduction should be done without leaving any visible tumor, and HIPEC can only be effective in this case (19). Systematic CRS, defined and standardized by Sugarbaker, includes peritonectomy and visceral organ resections $(10,19)$. According to this standardization, peritonectomy is divided into five regions: right and left diaphragmatic, anterolateral abdominal wall, subhepatic and bursa omentalis, and pelvic peritonectomy. Distal pancreas and spleen can be resected en bloc or separately by left upper quadrant diaphragmatic peritonectomy. Splenectomy is usually performed with large omentum resection or left diaphragm stripping. If there is no tumoral infiltration in the spleen, splenectomy is not performed (20). At this stage, if the tail of the pancreas is involved, distal pancreatectomy should be resected en bloc with omentectomy and splenectomy. Figure 2 and Figure 3 shows the patient who was operated on for PMP before and after resection. 
Table 1. Comparison of patients with and without distal pancreatectomy + splenectomy (DPS) in all patients who underwent CRS + HIPEC

\begin{tabular}{|c|c|c|c|c|}
\hline & CRS+ HIPEC & CRS + HIPEC + DPS & Total & p Value \\
\hline Total & $72(84.7 \%)$ & $13(15.3 \%)$ & 85 & \\
\hline \multicolumn{4}{|l|}{ Gender } & \multirow{3}{*}{0.531} \\
\hline Women & $40(55.55 \%)$ & $6(46.15 \%)$ & $46(54.11)$ & \\
\hline Men & $32(44.44 \%)$ & $7(53.84 \%)$ & $39(45.88)$ & \\
\hline Age & $55.05 \pm 1.14$ & $50.23 \pm 1.35$ & & 0.264 \\
\hline \multicolumn{4}{|l|}{ Location of primary tumor } & \multirow{7}{*}{0.535} \\
\hline Colon & $25(34.72 \%)$ & $7(53.84 \%)$ & $32(37.64 \%)$ & \\
\hline Stomach & $15(20.83 \%)$ & $4(30.76 \%)$ & $19(22.35 \%)$ & \\
\hline PMP & $15(20.83 \%)$ & $1(7.69 \%)$ & $16(18.82 \%)$ & \\
\hline Ovary & $11(15.27 \%)$ & $1(7.69 \%)$ & $12(14.11 \%)$ & \\
\hline Small intestine & $4(5.55 \%)$ & 0 & $4(4.70 \%)$ & \\
\hline Mesothelioma & $2(2.77 \%)$ & 0 & $2(2.35 \%)$ & \\
\hline \multicolumn{4}{|l|}{ ECOG } & \multirow{5}{*}{0.54} \\
\hline ECOG0 & $11(15.27 \%)$ & $2(15.38 \%)$ & $13(15.3 \%)$ & \\
\hline ECOG1 & $41(56.94 \%)$ & $6(46.15 \%)$ & $47(55.3 \%)$ & \\
\hline ECOG2 & $16(22.22 \%)$ & $5(38.46 \%)$ & $21(24.7 \%)$ & \\
\hline ECOG3 & $4(5.55 \%)$ & 0 & $4(4.7 \%)$ & \\
\hline Primary & $28(38.88 \%)$ & $4(30.76 \%)$ & $32(37.64 \%)$ & \multirow{2}{*}{0.578} \\
\hline Recurrence & $44(61.11 \%)$ & $9(69.23 \%)$ & $53(62.35 \%)$ & \\
\hline \multicolumn{4}{|l|}{ Peritonectomy } & \multirow{3}{*}{0.94} \\
\hline Yes & $27(37.5 \%)$ & $5(38.46 \%)$ & $32(37.64 \%)$ & \\
\hline No & $45(62.5 \%)$ & $8(61.53 \%)$ & $53(62.35 \%)$ & \\
\hline \multicolumn{4}{|l|}{ Ostomy } & \multirow{3}{*}{0.397} \\
\hline Yes & $19(26.38 \%)$ & $2(15.38 \%)$ & $21(24.7 \%)$ & \\
\hline No & $53(73.62 \%)$ & $11(84.62 \%)$ & $64(75.3 \%)$ & \\
\hline Length of stay (day) & $13(4-109)$ & $15(5-50)$ & $14(4-109)$ & 0.222 \\
\hline $\mathrm{PCl}$ & $6(0-30)$ & $7(0-26)$ & $7(0-30)$ & 0.598 \\
\hline Operation time (hour) & $6.5(2-15)$ & $7(3-12)$ & $7(2-15)$ & 0.130 \\
\hline Peroperative blood transfusion & $19(26.38 \%)$ & $2(15.38 \%)$ & $21(24.7 \%)$ & 0.397 \\
\hline \multicolumn{4}{|l|}{ Postoperative complication } & \multirow{3}{*}{0.026} \\
\hline No & $35(48.61 \%)$ & $2(15.38 \%)$ & $37(43.52 \%)$ & \\
\hline Yes & $37(51.38 \%)$ & $11(84.61 \%)$ & $48(56.47 \%)$ & \\
\hline \multicolumn{4}{|l|}{ Complication grade } & \multirow{7}{*}{0.05} \\
\hline None & $36(50 \%)$ & $2(15.38 \%)$ & $38(44.70 \%)$ & \\
\hline Minor1 & $8(11.11 \%)$ & $1(7.69 \%)$ & $9(10.58 \%)$ & \\
\hline Minor2 & $11(15.27 \%)$ & $3(23.07 \%)$ & $14(16.47 \%)$ & \\
\hline Major3 & $11(15.27 \%)$ & $5(38.46 \%)$ & $16(18.8 \%)$ & \\
\hline Major4 & $4(5.55 \%)$ & 0 & $4(4.70 \%)$ & \\
\hline Major5 & $2(2.77 \%)$ & $2(15.38 \%)$ & $4(4.70 \%)$ & \\
\hline \multicolumn{4}{|l|}{ Complication grade } & \multirow{3}{*}{0.02} \\
\hline Grade $0,1,2$ (none and minor) & $55(76.38 \%)$ & $6(46.15 \%)$ & $61(71.76 \%)$ & \\
\hline Grade 3, 4, 5 (major) & $17(23.61 \%)$ & $7(53.84 \%)$ & $24(28.23 \%)$ & \\
\hline \multicolumn{4}{|l|}{ Survival } & \multirow{3}{*}{0.268} \\
\hline Ex & $27(37.5 \%)$ & $8(61.5 \%)$ & $35(41.2 \%)$ & \\
\hline Living & $45(62.5 \%)$ & $5(38.5 \%)$ & $50(58.8 \%)$ & \\
\hline Median survival & 18 & 19 & 18 & \multirow{5}{*}{0.018} \\
\hline time (months) & (1 - 47 months) & (1-80 months) & (1-80 months) & \\
\hline \multicolumn{4}{|l|}{ Multiorgan resection } & \\
\hline$\leq 3$ organs & 56 & 6 & 62 & \\
\hline$>3$ organs & 16 & 7 & 23 & \\
\hline Albumin (gr/L) (Mean, SD) & $4.249 \pm 0.509$ & $4.232 \pm 0.423$ & $4.247 \pm 0.496$ & 0.92 \\
\hline
\end{tabular}

CRS + HIPEC: Cytoreductive surgery and hyperthermic intraperitoneal chemotherapy, DPS: Distal pancreatectomy plus splenectomy, PMP: Pseudomyxoma peritonei, ECOG: The Eastern Cooperative Oncology Group Score, PCl: Peritoneal carcinomatosis index. 
Table 2. Postoperative complications in all patients who underwent CRS + HIPEC

\begin{tabular}{|l|l|}
\hline & $\begin{array}{c}\text { Total } \\
\text { (85 patients) }\end{array}$ \\
\hline Postoperative complications & \\
\hline None (grade $\mathbf{0 )}+$ Minor (grade 1, 2) & $61(71.7 \%)$ \\
\hline Major (grade 3, 4, 5) & $24(28.3 \%)$ \\
\hline Gastrointestinal complications & \\
\hline Anastomotic leak & 5 \\
\hline Enterocutan fistula & 5 \\
\hline Intraabdominal collection, abscess & 5 \\
\hline Intraabdominal bleeding & 2 \\
\hline Ileus & 3 \\
\hline Liver abscess, cholangitis & 2 \\
\hline Pancreatic fistula & 1 \\
\hline Reoperation & 1 \\
\hline Pulmonary complications & \\
\hline Atelectasis & 1 \\
\hline Pneumonia & 2 \\
\hline Pleural effusion & 2 \\
\hline Re-Intubation & 2 \\
\hline Neurological complications & 2 \\
\hline Hematological complications & 1 \\
\hline Nephrotoxicity and acute renal failure & 5 \\
\hline Gastrocnemius compartment syndrome & 1 \\
\hline Mortality & 3 \\
\hline
\end{tabular}

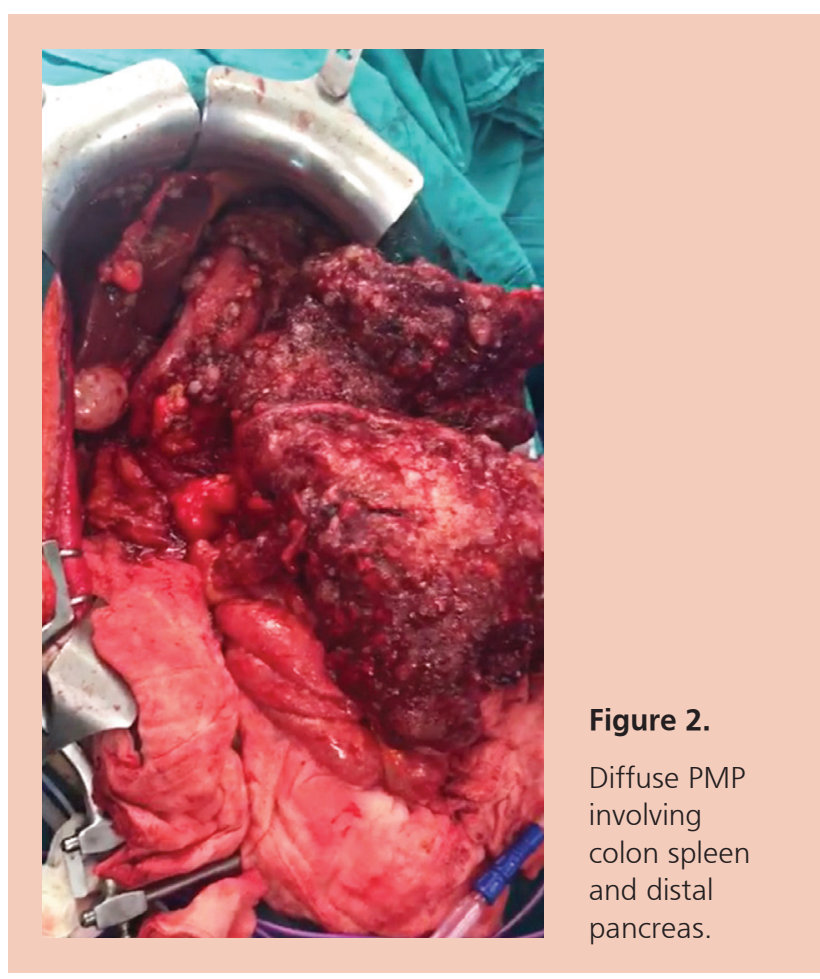

Morbidity and mortality rates are also high after such aggressive and long-lasting surgeries, and they increase in correlation with the size of the resection (21). This procedure, which was given $52 \%$ morbidity and $17 \%$ mortality rates in the first meta-analyzes, has been shown to be performed with $33 \%$ morbidity and $2.8 \%$ mortality in recent meta-analyzes with the completion of the learning curve $(8,22)$. When all patients were evaluated in our series, major morbidity was observed in 24 patients $(28.2 \%)$ and mortality in 3 patients (3.5\%) in total.

Piso et al. published the retrospective data of 2149 CRS + HIPEC patients from 52 hospitals, and reported the splenectomy rate as $20.1 \%$ and the pancreatectomy rate as $5.3 \%$. In their series, they showed that while pancreatectomy is the most effective factor on morbidity, it does not affect mortality. When these patients were examined, the $C C / 0+C C / 1$ rate was found to be $65.89 \%$ (22). In our series, DPS was performed to 13 (15.3\%) patients. We think that the reason for this high rate in our series is due to the possibility of providing $\mathrm{CC} / 0$ by pancreatectomy in all patients. More aggressive and long-lasting $\mathrm{CRS}$ is required to reach $\mathrm{CC} / 0$. The linear relationship between high $\mathrm{PCl}$, long operation time, the number of peritonectomy areas, the number of resected organs and postoperative major morbidity has been shown in various studies $(23,24)$. In our series, no difference was found between the groups in terms of the number of peritonectomy areas, $\mathrm{PCl}$, and operation time when the DPS group

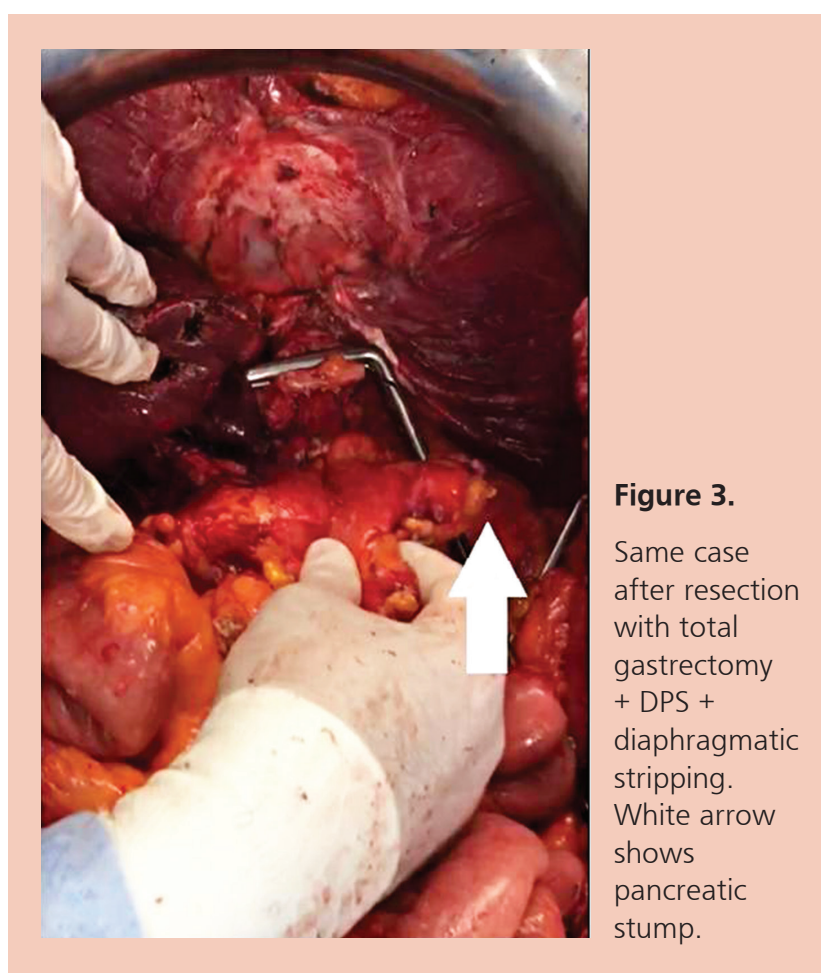


was compared with the non-DPS group. From these results, we saw that the postoperative major complication rates increased in the same patient group only with the addition of DPS. The most common major complications after DPS were intra-abdominal abscess requiring percutaneous drainage and intestinal fistulae. Pancreatic fistula developed in only one patient and early mortality was observed in two patients.

In the series published by Deraco et al, they found a rate of $8.8 \%$ pancreatic fistula in patients who underwent only splenectomy. They reported that this rate is higher than fistulas that develop splenectomies due to hematological malignancies (1-2\%), and they argued that the possible reasons for this may be due to pancreatic trauma, more thermal injury during cytoreduction, and the negative effects of hyperthermic chemotherapy (25). In this series they published, they gave the number of patients who underwent distal pancreatectomy with splenectomy as two. Canner et al. compared patients who underwent CRS + HIPEC with patients who underwent DPS for pancreatic adenocarcinoma and showed that the rates of postoperative pancreatic fistula (POPF) were the same, but the fistula was more severe in the HIPEC group (26). In the same study, they showed that PCI had no effect on the development of pancreatic fistula in patients who underwent distal pancreatectomy. In our series, POPF developed in only one patient in the DPS group. When we look at the patients who underwent splenectomy in the group that underwent only CRS + HIPEC, no POPF was observed, although there were 11 patients who had splenectomy.

In our study, we showed that DPS can be performed to achieve CCO resection, but it has statistically increased major complication rates compared to other patients. In a multicenter study published by Schwartz et al., DPS was performed with CRS + HIPEC in 105 patients. The first 30-day mortality was found $5.9 \%$ and the major complication rate $44 \%$ (27). The authors argued that DPS is not a contraindication to the operation and that it can be performed with acceptable morbidity and mortality. Similarly, Doud et al. showed that the addition of DPS $(6.5 \%)$ in a series of 63 patients had increased major morbidity and similar mortality rates, and emphasized that this procedure should not be avoided in cases where CCO resection could be achieved (28).

\section{REFERENCES}

1. Yoo HJ, Hong JJ, Ko YB et al. Current practices of cytoreductive surgery and hyperthermic intraperitoneal chemotherapy in the treatment of peritoneal surface malignancies: an international survey of oncologic surgeons. World J Surg Oncol 2018;16:92.
When the long-term follow-up of the patients were examined, no statistically significant difference was found between the two groups in terms of survival. Simkens et al. stated in their study that complications seen in the early period increased recurrences and therefore shortened survival (9). In our study, the addition of DPS increases early complications but does not affect life expectancy. This let us to think that both groups benefit from CCO resection and although it increases early complications, the addition of DPS should have the same survival time as peritoneal carcinomatosis without distal pancreatic invasion. Sullivan et al. performed distal pancreatectomy in 37 patients who underwent CRS + HIPEC and reported that progression free survival (PFS) was low in the DPS group (29). Considering this group, it was seen that only $69 \%$ of the patients who underwent DPS could have CC/0 with CC/1 and this rate was $90 \%$ in the other group, and this difference was significantly lower. Considering that the $\mathrm{CC} / 0$ rate will be even lower, it comes to mind that the PFS may be low for this reason. The reason for the lack of difference in terms of survival in our series can be explained by the fact that all patients are comprised of patients with $\mathrm{CC} / 0$ resection, which is the main determinant of survival.

The addition of DPS increases postoperative major complications in patients undergoing CRS + HIPEC, but has no effect on survival. We think that the reason for its ineffectiveness on survival is the achievement of CCO resection, which is the goal of CRS + HIPEC surgery in both groups. We think that DPS can be performed if necessary for a complete cytoreduction, but it should be known that it increases the development of postoperative major complications and patient follow-up should be done accordingly.

\section{Acknowledgements: None}

Funding: No funding was received from any source for the article.

Conflicts of interest: All authors declare no conflicts of interest.

Ethics: This study was conducted in accordance with the Declaration of Helsinki. Ethics committee approval was received from Ministry of Health, Ankara City Hospital (24.03.2021/E2-21-353).

2. Goéré $D$, Malka D, Tzanis D, et al. Is there a possibility of a cure in patients with colorectal peritoneal carcinomatosis amenable to complete cytoreductive surgery and intraperitoneal chemotherapy? Ann Surg 2013;257:1065-71. 
3. Chia CS, You B, Decullier E, et al; BIG RENAPE Group. Patients with peritoneal carcinomatosis from gastric cancer treated with cytoreductive surgery and hyperthermic intraperitoneal chemotherapy: Is cure a possibility? Ann Surg Oncol 2016;23:1971-9.

4. Spiliotis J, Halkia E, Lianos E, et al. Cytoreductive surgery and HIPEC in recurrent epithelial ovarian cancer: a prospective randomized phase III study. Ann Surg Oncol 2015;22:1570-5.

5. Benhaim L, Faron M, Gelli M, et al. Survival after complete cytoreductive surgery and HIPEC for extensive pseudomyxoma peritonei. Surg Oncol 2019;29:78-83.

6. Li Y, Yu Y, Liu Y. Report on the 9(th) International Congress on Peritoneal Surface Malignancies. Cancer Biol Med. 2014;11:281-4.

7. Dodson RM, Kuncewitch M, Votanopoulos KI, et al. Techniques for cytoreductive surgery with hyperthermic intraperitoneal chemotherapy. Ann Surg Oncol 2018;25:2152-8.

8. Huang CQ, Min Y, Wang SY, et al. Cytoreductive surgery plus hyperthermic intraperitoneal chemotherapy improves survival for peritoneal carcinomatosis from colorectal cancer: a systematic review and meta-analysis of current evidence. Oncotarget 2017;8:5565783.

9. Simkens GA, van Oudheusden TR, Luyer MD, et al. Serious postoperative complications affect early recurrence after cytoreductive surgery and HIPEC for colorectal peritoneal carcinomatosis. Ann Surg Oncol 2015;22:2656-62.

10. Sugarbaker PH, Editor. Cytoreductive surgery \& perioperative chemotherapy for peritoneal surface malignancy. Textbook and video atlas. Woodbury: CineMed Publishing; 2012.

11. Oken MM, Creech RH, Tormey DC, et al. Toxicity and response criteria of the Eastern Cooperative Oncology Group. Am J Clin Oncol 1982;5:649-55.

12. Kondrup J, Rasmussen HH, Hamberg O, Stanga Z; Ad Hoc ESPEN Working Group. Nutritional risk screening (NRS 2002): a new method based on an analysis of controlled clinical trials. Clin Nutr 2003;22:321-36.

13. Sugarbaker PH. Peritonectomy procedures. Surg Oncol Clin N Am 2003; 12:703-27.

14. Baratti D, Kusamura S, Mingrone E, et al. Identification of a subgroup of patients at highest risk for complications after surgical cytoreduction and hyperthermic intraperitoneal chemotherapy. Ann Surg 2012;256:334-41.

15. Glehen O, Kwiatkowski F, Sugarbaker PH, et al. Cytoreductive surgery combined with perioperative intraperitoneal chemotherapy for the management of peritoneal carcinomatosis from colorectal cancer: a multi-institutional study. J Clin Oncol 2004;22:3284-92.

16. Elias D, Goéré D, Dumont F, et al. Role of hyperthermic intraoperative peritoneal chemotherapy in the management of peritoneal metastases. Eur J Cancer 2014;50:332-40.
17. Bonnot PE, Piessen G, Kepenekian V, et al; FREGAT and BIG-RENAPE Networks. Cytoreductive surgery with or without hyperthermic intraperitoneal chemotherapy for gastric cancer with peritoneal metastases (CYTO-CHIP study): A propensity score analysis. J Clin Oncol 2019;37:2028-40.

18. Spiliotis J, Halkia E, de Bree E. Treatment of peritoneal surface malignancies with hyperthermic intraperitoneal chemotherapy-current perspectives. Curr Oncol 2016;23:266-75.

19. Deraco M, Kusamura S, Corbellini C, et al. Treatment principles for peritoneal surface malignancies. Minerva Chir 2016;71:124-45.

20. Bao $P$, Bartlett $D$. Surgical techniques in visceral resection and peritonectomy procedures. Cancer J 2009;15:204-11.

21. Berger $Y$, Aycart S, Mandeli JP et al. Extreme cytoreductive surgery and hyperthermic intraperitoneal chemotherapy: Outcomes from a single tertiary center. Surg Oncol 2015;24:264-9.

22. Piso $P$, Nedelcut SD, Rau B et al. Morbidity and mortality following cytoreductive surgery and hyperthermic intraperitoneal chemotherapy: Data from the DGAV StuDoQ Registry with 2149 consecutive patients. Ann Surg Oncol 2019;26:148-54.

23. Kusamura S, Younan R, Baratti D, et al. Cytoreductive surgery followed by intraperitoneal hyperthermic perfusion: analysis of morbidity and mortality in 209 peritoneal surface malignancies treated with closed abdomen technique. Cancer 2006;106:1144-53.

24. Mehta SS, Gelli M, Agarwal D, Goéré D. Complications of cytoreductive surgery and HIPEC in the treatment of peritoneal metastases. Indian J Surg Oncol 2016;7:225-9.

25. Deraco M, Baratti D, Kusamura S, Laterza B, Balestra MR. Surgical technique of parietal and visceral peritonectomy for peritoneal surface malignancies. J Surg Oncol 2009;100:321-8.

26. Downs-Canner S, Ding Y, Magge DR, et al. A comparative analysis of postoperative pancreatic fistulas after surgery with and without hyperthermic intraperitoneal chemoperfusion. Ann Surg Oncol 2015;22:1651-7.

27. Schwarz L, Votanopoulos K, Morris D, et al. Is the combination of distal pancreatectomy and cytoreductive surgery with HIPEC reasonable?: Results of an international multicenter study. Ann Surg 2016;263:369-75.

28. Doud AN, Randle RW, Clark CJ, et al. Impact of distal pancreatectomy on outcomes of peritoneal surface disease treated with cytoreductive surgery and hyperthermic intraperitoneal chemotherapy. Ann Surg Oncol 2015;22:1645-50.

29. Sullivan BJ, Leigh NL, Bekhor EY, et al. Distal pancreatectomy in cytoreductive surgery with hyperthermic intraperitoneal chemotherapy: Identifying risk and improving patient selection. Am J Surg 2020;220:1235-41. 